\title{
The Relationship between Energy Literacy and Environmental Sustainability
}

\section{Catherine Dwyer}

Seidenberg School of Computer Science and Information Systems, Pace University, New York, USA.

Email: cdwyer@pace.edu

Received June 21 ${ }^{\text {st }}$, 2011; revised July $18^{\text {th }}$, 2011; accepted July $25^{\text {th }}, 2011$.

\begin{abstract}
Sustainability, first identified as a characteristic of eco-systems, is the capacity to maintain a process indefinitely. Environmental sustainability receives significant public and government attention, triggered by concerns about climate change, decreasing energy supplies, and increasing food costs. Colleges and universities receive positive notice for their greening efforts, and the academy is expected to be a leader in efforts to improve sustainability. Therefore coursework and curricula must be developed to train students about sustainable resource consumption processes. This paper describes curricula materials related to energy literacy, defined as conceptual fluency with the economic and social components of energy use. These materials were developed and piloted over a three year period, and were tested with a pre- and post-course survey administered with questions based on the New Environmental Paradigm (NEP) and Environmentally Responsible Behavior (ERB). The findings of this study suggest that discussion of sustainability with disaster themes triggers anxiety that interferes with the development of ERB. In contrast, materials emphasizing the pragmatic necessity and benefits derived from sustainable practices relate to improvements in ERB. This suggests sustainability curricula should mitigate anxiety aroused by the topic, and instead emphasize pragmatic motivations for changing energy consumption patterns.
\end{abstract}

Keywords: Sustainability, Energy Literacy, Information Technology Literacy, Social Impact of Technology, Climate Change

\section{Introduction}

Watson, Boudreau and Chen argue that the Information Systems (IS) community, and the academic community as a whole, must take a new direction in support of sustainable development [1]. They call for "IS researchers, educators, journal editors, and association leaders to demonstrate how the transformative power of IS can be leveraged to create an ecologically sustainable society" [1]. Watson et al. define 'Green IS' as the design and development of information systems in support of sustainable business processes. Green IS encourages the application of information systems thinking and skills to initiatives across all functions of the organization, from logistics, to waste management, to communicating consumption information to customers.

IS academics and professionals can contribute as researchers, organizers of Green IS tracks in conferences, editors of Green IS special issues of journals, and through the development of Green IS curricula. This paper reports on the development of curricula that specifi- cally focuses on energy use and consumption practices.

\subsection{Rationale for Focus on Energy and Sustainability}

Green IS incorporates a wide range of topics, including increasing the efficiency of data centers, monitoring and providing feedback on consumption patterns, and applying algorithms to processes to encourage energy efficiency. There is a natural alignment between traditional IS, which focuses on increasing the efficiency of the enterprise with respect to the bottom line, and the focus of Green IS on increasing the efficient use of non-renewable resources [2,3].

Climate change is a pressing threat to the sustainability of life on earth as we know it [1]. It is a highly complex problem that is unpredictable, reflecting an intricate interaction of organizational production processes, government management and regulation, natural forces, and individual behavior [4].

This project focuses on a sub-set of the environmental 
sustainability domain, namely energy use and consumption patterns. This focus was selected for the following reasons. First, the burning of fossil fuel is by far the highest contributor of green house gases linked to climate change, and any progress on climate change must address the use of fossil fuels [5]. Secondly, energy is a tangible and approachable topic for students, who have everyday experience with energy. Finally, there is a large collection of publicly available energy data maintained and updated by the US Energy Information Administration [6], containing thirty years of continuous and varied measures of energy use. This data served as the primary resource for data analysis assignments developed for this project.

\subsection{Energy Consumption Patterns in the US}

For the US, individual consumption choices are a key determinant for reducing energy use and carbon emissions. While the US was edged out in 2010 by China as the world's largest consumer of energy [7], US per capita energy use is 327 Giga Joule per year (GJ), compared to 176 GJ for Germany, 169 GJ for Japan and 47 GJ for China [8]. Although China's use of energy is growing rapidly [9], an argument can be made that this increase relates to the manufacture of products bound for US markets. If the calculation of a product's carbon footprint includes full life cycle emissions [10], then a significant portion of China's energy use feeds US consumption patterns. US energy consumption is roughly $40 \%$ higher than prosperous EU countries. If US consumers adopted energy use patterns more in line with $\mathrm{EU}$ habits, this would reduce carbon emissions by at least $2.5 \mathrm{GT}$ of $\mathrm{CO}_{2}$ per year [5].

Energy use does decline with dramatic price increases, but raising the cost of energy to reduce consumption is far from ideal. The oil shocks of the 1970s led to worldwide economic hardship [11], and the rapid run up in oil prices was a factor in the 2008 global recession [9]. Effective non-economic mechanisms must be identified and exploited. Therefore non-economic efforts, such as the development of curricula that promote sustainability, will be an important component of global efforts to reduce energy use without causing widespread economic hardship.

While this paper focuses on US energy consumption, sustainability is a global issue. These materials offer a case study of US energy use that can be adapted to other countries. SIGGreen, a special interest group (SIG) of the Association of Information Systems, was formed in 2010 to support the role of information systems in sustainability. The mission of SIGGreen is to provide a platform for international collaboration among researchers and educators to promote the design and development of infor- mation systems in support of environmental sustainability. For more information about SIGGreen, please go to http://siggreen.wikispaces.com/.

\subsection{Cultural Factors Related to Consumption Patterns}

In his book Collapse: How Societies Choose to Fail or Succeed, Jared Diamond argues that effective management of environmental challenges depends on "the society's responses to its environmental problems" [12, p. 11]. Diamond compares successful responses to deforestation by Japan, to unsuccessful responses on Easter Island. Diamond argues cultural values affect whether a society can address, or will even attempt to address pressing environmental problems.

Culture must adopt new energy use patterns to overcome climate change. Noting the efficient habits of the Japanese, the environmental researcher Vacal Smil says "they waste everything less, less food, less energy. So if the whole world wants to eat like Japan it's still dicey but kind of doable, but if the world wants to replicate the two biggest wasters in the world, the U.S. and Canada, there is no hope for anybody" [13].

Changing US cultural values to support sustainability is an enormous challenge. But the alternatives are to ignore the threat of climate change, or trigger economic damage from increases in the cost of energy. The next section describes an example of an education effort to change cultural values by introducing the concept of energy literacy.

\section{Development of the Energy Literacy Construct}

The focus of this project is the development of curricula to show the correlation between energy use patterns, climate change, and environmental sustainability. While the consumption of energy is an everyday occurrence and a frequent topic of political discourse, the dynamics of energy consumption are in fact extremely complex. Everyday familiarity with energy hides the deep complexities that govern its pricing and availability [14]. It is a proposition of this research that consumers' surface level understanding of energy dynamics contributes to complacency about the intense impact of burning fossil fuel on the global environment.

\subsection{Complexities in the Pricing and Availability of Energy}

Complexities in factors related to the supply and cost of energy are quite significant. First of all, energy amounts are described using measurement terms such as British Thermal Units (BTUs), Mega Watts (MW), or Giga Joules of energy (GJ), that have no tangible context to 
the average person. They are also not readily convertible. It is certainly not common knowledge how many BTUs a person consumes in an average day, or for that matter how many MWs or GJs. Some measurement units have archaic origins. A "barrel of oil" is an artifact of the size of English wine barrels, which were reused to hold petroleum for the first functioning oil wells [11]. A standard barrel contains 42 US gallons of oil, which when refined typically produces 19.5 gallons of gasoline [11]. Roughly speaking, every time a consumer fills up their gas tank, they are using the major portion of a barrel of oil.

Publicly reported oil prices also have hidden complexities. The price for an oil futures contract is commonly cited by the media when reporting on oil costs. Oil futures contracts are traded on the New York Mercantile Exchange (NYMEX). These contracts specify a certain number of barrels of light, sweet crude oil, a type preferred for its low sulfur and high yields [14], to be delivered by a specified date to Cushing, Oklahoma [15]. Like many futures contracts, prices are quite volatile, and are purchased as an investment hedge that rarely leads to actual delivery of oil. Instead oil producers use the futures price as a benchmark to set prices for other products. Even though oil futures prices are reported on a daily basis, there is no one to one ratio, or even a clear relationship between the reported "price of oil", and what people pay for gasoline or other petroleum products. This creates confusion and anger on the part of consumers and politicians alike when the price of oil futures moves down while the price of gasoline does not [11].

Oil industry experts such as Daniel Yergin and Kenneth Defeyes argue that the price of oil has an extreme degree of volatility due to fundamental characteristics about its production and transportation [11,14]. Oil is produced and consumed in a continuous flow from oil field to refineries, to cars, homes, and industries. This can be modeled as a flow network, as described in graph theory. For a flow network to function smoothly there must be stability and consistency in both the rate of production and the rate of consumption. Any significant change in either production or consumption severely disrupts the flow network, resulting in either large price hikes when production is less than consumption, or deep price drops when production exceeds consumption [14].

Recently the price of oil was quite volatile in 2008 and 2009, and during the oil shocks of the 1970s. However this is nothing new. Oil has a history of extreme price volatility that has persisted since the beginning of the 20th century. At one point in the 1930s, oil was trading at ten cents a barrel, which nearly drove the US oil industry into complete collapse. Only the intervention of the Railroad Commission of Texas to strictly control produc- tion so that it matched consumption allowed the recovery of the industry [11]. The degree of oil price volatility is not found in any other segment of the consumer market. While consumers have a general understanding of supply and demand, the rapid price swings for petroleum creates distrust over hoarding of supply when prices go up, or doubts about constrained resources when prices drop [14].

Another source of confusion is the price difference between fossil fuels and renewable alternatives such as solar or wind power. When compared by the unit cost of a quantity of energy, renewables are much more expensive. Even among fossil fuels, coal, the dirtiest fuel of all, is the least expensive. There are expectations by consumers that the cost difference will be made up by government subsidies or that innovation will eventually drive down the cost of renewables compared to fossil fuels [16]. However, an important reason fossil fuels are less expensive is that the damage caused by carbon emissions is treated as an externality to the price. An externality is an economic term that describes a cost associated with a market transaction that is not part of the selling price. It is instead a cost is borne by society as a whole. In a price driven market, there is great incentive to externalize as many factors as possible from transaction costs, because lower prices result in more sales. As long as the cost of carbon emissions remains an externality, renewable energy sources will be more expensive [17].

If confusion about energy causes complacency about changing consumption behavior, then it follows that a program to increase awareness of the complexities and underlying components of energy use may encourage more sustainable energy consumption patterns. Therefore the concept of Energy Literacy is introduced. Energy Literacy is defined as a baseline fluency and knowledge of complexities related to energy use. Topics include differences between fossil fuels, renewable energy alternatives, and the link between consumption decisions and environmental impact. Energy literacy supports an understanding of the impact of energy use on sustainability. The objective of energy literacy is an increase in sustainable energy use behavior $[18,19]$.

Literacy is defined with both a cognitive and social component. It is the "ability to identify, understand, interpret, create, communicate, compute and use printed and written materials associated with varying contexts ... enabling individuals ... to participate fully in their community and wider society” [20]. Literacy can be applied to other domains by identifying a baseline cognitive fluency, and demonstrating how this fluency supports a more engaged citizenry. Examples include information technology literacy [21], information and communications technology e-readiness [22], and quantitative liter- 
acy [23].

Energy literacy relates to information technology literacy, because computer driven data analysis is the basis of all scientific simulation and study of climate change. Energy costs and consumption projections derive from complex mathematical formulas applied to gigabytes of energy use data. Not simply a vessel for energy information, technology can serve as an active agent in the framing and reinforcement of transformative understanding and perspectives [24].

\subsection{The Need for More Sophisticated Energy Curricula}

Economic and social complexities of energy use cause public confusion and disassociation from the urgent need to change consumption habits. One way to influence the culture of energy consumption is through education. Sustainability curricula materials are abundantly available on the Web for grades K-12, but they target younger children with cartoon characters and talking animals that urge students to "be green".

There is not as much material available for the college audience. It is important to invest in the development of these materials because research shows current high school students are uninformed about energy issues [19]. The potential of information technology to support awareness of sustainability has not been fully explored [25]. There is a pressing need for development in human computer interfaces to create data visualization tools that display energy use patterns [26].

Many professions have declared their commitment to the support of sustainability. The academic community has created organizations such as the American College and University Presidents' Climate Commitment in support of these initiatives [27]. The next section describes the development of the energy literacy materials, and their use in an undergraduate course.

\section{Development of the Energy Literacy Curriculum Materials}

The Energy Literacy materials described here were developed at a private urban university in the Northeast United States. They were designed as a module for the basic computing literacy course, Introduction to Computing. This course is required for all undergraduates at the university. It provides an introduction to the role of information technology within society and the economy. The course is three credits, with two hours held in a computer classroom combined with a required online portion equivalent to one hour of classroom instruction (commonly known as a hybrid or blended learning course). Students get hands on instruction in a computer classroom with spreadsheets (Excel), designing web pages (HTML), and programming (JavaScript).

To emphasize the widespread integration of technology across multiple professions, the course also features an interdisciplinary component. These materials were developed to add Sustainability as the interdisciplinary component of the course. Other components currently being offered at the school include computer forensics and the social impact of technology.

The Energy Literacy materials were piloted in an abbreviated form during the spring 2008 semester. They were then included in eight sections of the course between the fall 2008 semester and the spring 2010 semester.

The Energy Literacy materials have three components. The first component is a sequence of data analysis exercises that instruct students in the use of Excel using data obtained from the Energy Information Administration (EIA), a division of the US Department of Energy [28]. The EIA was established in 1977 in response to the oil shocks of the 1970s. Their mission is to document energy production and consumption patterns, and make forecasts as to future supply and demand. Their data is freely available on their Web site, mostly in spreadsheet format. Their data and reports are widely used by public and private organizations in planning and budgeting energy expenditures.

The second component of the Energy Literacy materials is a series of reading assignments and required participation in an online discussion board. This course, as a blended course, uses online discussion as part of the required material for the class. For example, a news article was assigned about the connection between rising oil prices and gasoline supply [29]. They also were assigned “The Inevitable Peaking of Global Oil Production” [30], and a chapter from an information systems text on the role of information technology in promoting sustainability [25].

The third component of the Energy Literacy materials was a capstone team project. Students were formed into groups and selected a company to analysis with regard to their sustainability initiatives. Examples of companies selected include Apple, Dell, Starbucks, and Whole Foods. More specific information about the course assignments can be found in the Appendix.

\section{Research Methodology}

In order to capture data on the effect of the energy literacy materials on students' attitudes towards sustainability, a research design was created to administer a survey of measures in the beginning of the course, and at the end of the course. A literature review was conducted to find established, validated measures of environmentally responsible behavior. 
The review uncovered two established scales, the New Environmental Paradigm (NEP), and Environmentally Responsible Behavior (ERB). Both were incorporated into a pre- and post-course survey, along with general demographic questions, and open ended questions about sustainability. The survey questions are listed in Table 1. Scales such as NEP and ERB that measure relationships between attitudes and behavior draw on the efforts of Fishbein and Ajzen, whose work includes the Theory of Reasoned Action [31] and the Theory of Planned Behavior [32]. When conceptualizing the relationship between attitude and behavior, both theories focus on the construct known as behavioral intention, which is the measure of the relative strength of a person's intention to perform a behavior [31,32].

Research into environmental attitudes has made a distinction between general attitudes towards sustainability,

Table 1. Summary of survey questions.

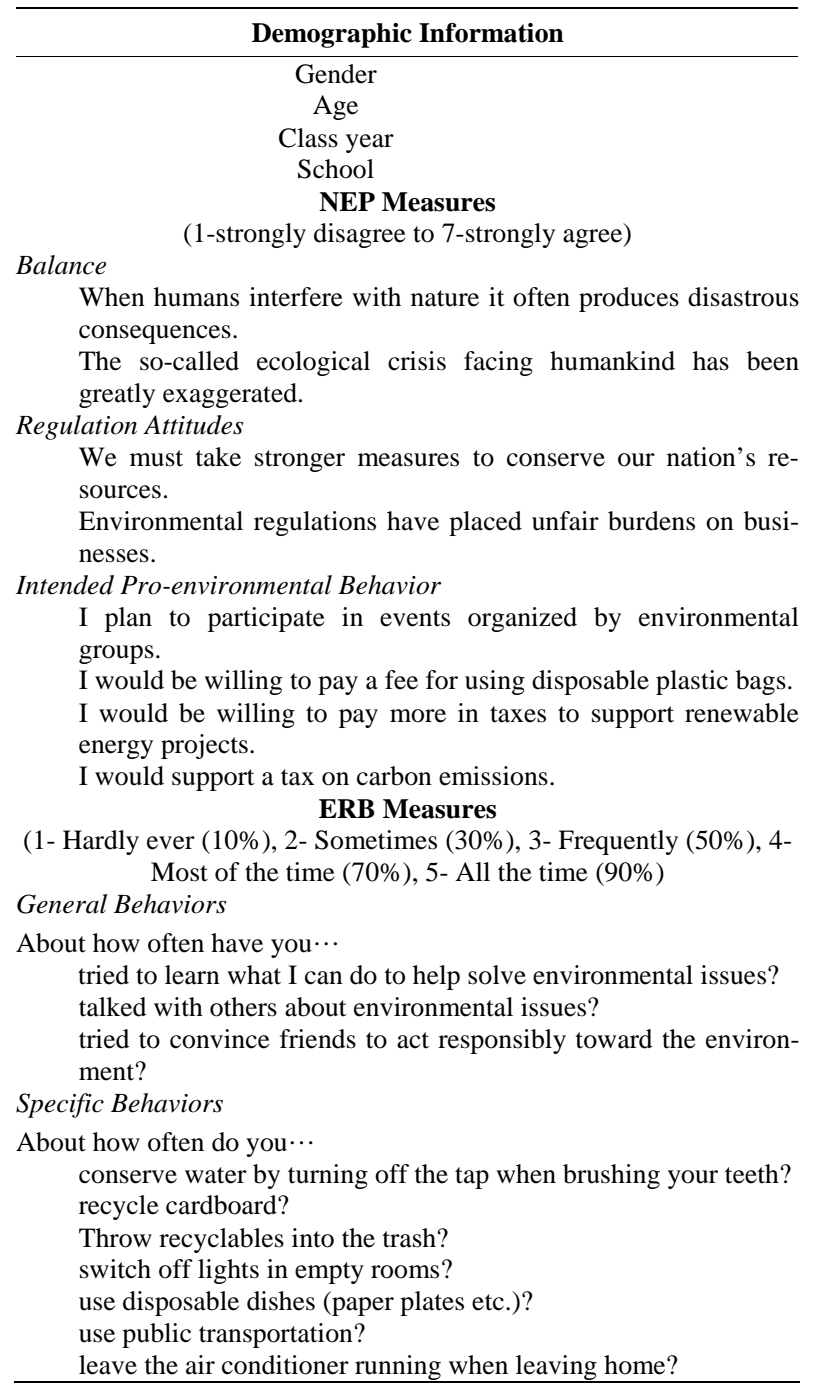

and concerns about specific, local environmental problems [33]. NEP focuses on more general attitudes towards sustainability, and has been revised several times to capture a more accurate picture of changing attitudes and beliefs about the environment. It has been used in multiple surveys to study attitudes in a variety of populations, including secondary school students, colleges students, and organized environmentalists [34]. The measures used in this study were from the work of Cordano et al. [35] and Dunlap et al. [36].

A criticism of NEP is that it does not measure specific environmental concerns or pro-environmental behaviors [33]. Many studies have supplemented the NEP with questions regarding specific types of environmentally responsible behavior (ERB). The questions included in this survey were adapted from work by Vaske and Kobrin [37], Smith-Sebasto and D’Costa [38], Kaplan [39] and Mobley et al. [33].

\section{Summary of Results}

A total of 188 students took the pre-course survey, and 147 took the post-course survey. Female students made up $54 \%$ of the participants, compared to $45 \%$ male, and $1 \%$ who declined to answer. Most were first year students (83.3\%). The majority were business majors (68\%), followed by Liberal Arts (28\%) or undecided (4\%). A chi squared analysis of the demographic data showed no significant differences in the characteristics of the populations for the pre-course versus the post-course survey.

The first step in the data analysis was to conduct a univariate comparison of the pre- and post-course means for each survey item. A summary of the pre- and postcourse means for the measures adapted from the NEP scale are listed in Table 2 . These measures use a seven

Table 2. Results for NEP items.

\begin{tabular}{lcc}
\hline \multicolumn{1}{c}{ Measure } & $\begin{array}{c}\text { Pre } \\
(N=188)\end{array}$ & $\begin{array}{c}\text { Post } \\
(N=147)\end{array}$ \\
\hline $\begin{array}{l}\text { The so-called ecological crisis facing } \\
\text { humankind has been greatly exagger- } \\
\text { ated. }\end{array}$ & 3.016 & 3.143 \\
$\begin{array}{l}\text { I would be willing to pay a fee for us- } \\
\text { ing disposable plastic bags. }\end{array}$ & 3.086 & 3.252 \\
$\begin{array}{l}\text { I would support a tax on carbon emis- } \\
\text { sions. }\end{array}$ & 3.790 & 4.150 \\
$\begin{array}{l}\text { We must take stronger measures to } \\
\text { conserve our nation's resources. }\end{array}$ & 5.793 & 5.945 \\
$\begin{array}{l}\text { I would be willing to pay more in taxes } \\
\text { to support renewable energy projects. } \\
\begin{array}{l}\text { I plan to participate in events organized } \\
\text { by environmental groups. }\end{array}\end{array}$ & 4.167 & 4.247 \\
$\begin{array}{l}\text { Environmental regulations have placed } \\
\text { unfair burdens on businesses. } \\
\quad \text { When humans interfere with nature it } \\
\text { often produces disastrous consequences. }\end{array}$ & 3.622 & 3.911 \\
\hline
\end{tabular}

Range: 1 (SD)-7(SA). 
point scale. A summary of the means from the ERB scale is listed in Table 3. Measures from the ERB use a five point scale.

NEP measures positively worded with a mean above four indicate a pro-environmental attitude. This includes "When humans interfere with nature it often produces disastrous consequences." Some measures are reverse coded, so a mean below four indicates a pro-environmental attitude. This includes "The so-called ecological crisis facing humankind has been greatly exaggerated.”

While every NEP measure except one moved in a proenvironmental direction, none of the measures had significant differences between the pre- and post-course survey. Results for the measure "I would support a tax on carbon emissions" approached significance with a level of 0.056 .

Table 3 summarizes the pre- and post-course results for the ERB measures. These questions ask about a specific behavior with environmental consequences. Some behaviors are pro-environmental (such as recycling), and some are anti-environmental (keeping the air conditioner on when leaving home). Most items moved in a pro-environmental direction except the measure about recycling cardboard, which declined, and using disposable dishes, which increased. No significant differences were found for ERB measures comparing the pre-course to the postcourse results.

Survey measures compared by gender showed some

Table 3. Results for ERB items.

\begin{tabular}{|c|c|c|}
\hline Measure & $\begin{array}{c}\text { Pre } \\
(N=188)\end{array}$ & $\begin{array}{c}\text { Post } \\
(N=147)\end{array}$ \\
\hline \multicolumn{3}{|l|}{ About how often have you ... } \\
\hline $\begin{array}{l}\text { Tried to learn what you can do to help } \\
\text { solve environmental issues? }\end{array}$ & 2.608 & 2.748 \\
\hline $\begin{array}{l}\text { Talked with others about environ- } \\
\text { mental issues? }\end{array}$ & 2.855 & 2.973 \\
\hline $\begin{array}{l}\text { Tried to convince friends to act respon- } \\
\text { sibly toward the environment? }\end{array}$ & 2.703 & 2.877 \\
\hline \multicolumn{3}{|l|}{ About how often do you $\cdots$} \\
\hline Recycle cardboard? & 3.269 & 3.259 \\
\hline Throw recyclables into the trash? & 2.733 & 2.726 \\
\hline $\begin{array}{l}\text { Leave the air conditioner running when } \\
\text { leaving home? }\end{array}$ & 2.348 & 2.190 \\
\hline $\begin{array}{l}\text { Use disposable dishes (paper plates } \\
\text { etc.)? }\end{array}$ & 2.604 & 2.714 \\
\hline Use public transportation? & 3.984 & 4.143 \\
\hline $\begin{array}{l}\text { Conserve water by turning off the tap } \\
\text { when brushing your teeth? }\end{array}$ & 3.385 & 3.432 \\
\hline Switch off lights in empty rooms? & 3.893 & 4.034 \\
\hline
\end{tabular}

1- Hardly ever (10\%), 2- Sometimes (30\%), 3- Frequently (50\%), 4- Most of the time (70\%), 5- All the time (90\%). significant differences (see Table 4). Males were significantly more likely to agree with: "The so-called ecological crisis facing humankind has been greatly exaggerated," ( $p<0.01$ ); "Environmental regulations have placed unfair burdens on businesses," ( $p<0.05)$; and report they throw recyclables in the trash, $(\mathrm{p}<0.05)$. Females were significantly more likely to report they "Tried to convince friends to act responsibly toward the environment," ( $p<0.0001$ ), and "Conserve water by turning off the tap when brushing your teeth," ( $p<0.05)$.

A puzzling result is that females are more likely to report they leave the air conditioner running when leaving home ( $\mathrm{p}<0.01)$. One possible explanation is that, anecdotally, female undergraduates make a concerted effort to avoid "sweating”, or "being sweaty". This reveals an instance where cultural values may be accommodated by

Table 4. Comparison of results by gender.

\begin{tabular}{|c|c|c|c|}
\hline Measure & $\begin{array}{c}\mathrm{M} \\
\mathbf{N}=\mathbf{1 5 0}\end{array}$ & $\begin{array}{c}F \\
N=181\end{array}$ & Sig. \\
\hline Scale 1 - 7 & & & \\
\hline $\begin{array}{l}\text { The so-called ecological crisis facing } \\
\text { humankind has been greatly exagger- } \\
\text { ated. }\end{array}$ & 3.311 & 2.884 & $* *$ \\
\hline $\begin{array}{l}\text { I would be willing to pay a fee for us- } \\
\text { ing disposable plastic bags. }\end{array}$ & 3.093 & 3.232 & \\
\hline $\begin{array}{l}\text { I would support a tax on carbon emis- } \\
\text { sions. }\end{array}$ & 3.954 & 3.961 & \\
\hline $\begin{array}{l}\text { We must take stronger measures to } \\
\text { conserve our nation's resources. }\end{array}$ & 5.730 & 5.983 & 0.080 \\
\hline $\begin{array}{l}\text { I would be willing to pay more in taxes } \\
\text { to support renewable energy projects. }\end{array}$ & 4.272 & 4.151 & \\
\hline $\begin{array}{l}\text { I plan to participate in events organized } \\
\text { by environmental groups. }\end{array}$ & 3.636 & 3.848 & \\
\hline $\begin{array}{l}\text { Environmental regulations have placed } \\
\text { unfair burdens on businesses. }\end{array}$ & 3.364 & 2.978 & $*$ \\
\hline $\begin{array}{l}\text { When humans interfere with nature it } \\
\text { often produces disastrous conse- } \\
\text { quences. }\end{array}$ & 4.780 & 5.061 & \\
\hline \multicolumn{4}{|l|}{ Scale $1-5$} \\
\hline $\begin{array}{l}\text { Tried to learn what you can do to help } \\
\text { solve environmental issues? }\end{array}$ & 2.593 & 2.724 & \\
\hline $\begin{array}{l}\text { Tried to convince friends to act re- } \\
\text { sponsibly toward the environment? }\end{array}$ & 2.483 & 3.028 & $* * *$ \\
\hline Recycle cardboard? & 3.287 & 3.260 & \\
\hline Throw recyclables into the trash? & 2.901 & 2.600 & $*$ \\
\hline $\begin{array}{l}\text { Leave the air conditioner running when } \\
\text { leaving home? }\end{array}$ & 2.040 & 2.475 & $* *$ \\
\hline $\begin{array}{l}\text { Use disposable dishes (paper plates } \\
\text { etc.)? }\end{array}$ & 2.649 & 2.646 & \\
\hline Use public transportation? & 4.000 & 4.094 & \\
\hline $\begin{array}{l}\text { Conserve water by turning off the tap } \\
\text { when brushing your teeth? }\end{array}$ & 3.225 & 3.561 & $*$ \\
\hline Switch off lights in empty rooms? & 3.828 & 4.061 & 0.090 \\
\hline
\end{tabular}

$* \mathrm{p}<0.05, * * \mathrm{p}<0.01, * * * \mathrm{p}<0.001$. 
more sophisticated temperature management technology to regulate air conditioning via remote control.

The next step was to conduct a factor and reliability analysis on the NEP and ERB scales. The NEP was examined with a principal components factor analysis. The results for the pre- and post-course survey were tested separately. A factor analysis of the pre-course data presented a solution with three factors. A factor analysis of the post-course data presented a solution with two factors. The NEP data was also examined using Cronbach's alpha. By dropping one item from the NEP ("When humans interfere with nature ...”), Cronbach's alpha results for the seven remaining questions was 0.670 for the precourse data and 0.733 for the post-course data.

While an alpha value of 0.7 or higher is optimal, in the case of exploratory research somewhat lower values have been accepted [40].

The seven questions from the NEP were added into a combined scale by adding the value for each measure together. One measure ("Environmental regulations have placed ...”) was reverse coded so that the direction of all questions in the scale was the same. The means for the combined NEP scale were compared using ANOVA for pre- and post-course results. The difference was not significant. The $\mathrm{F}$ value was 2.845 and the significance level was 0.093 .

Next the ERB measures were examined with a principal components factor analysis. The pre-course data presented a three factor solution and the post-course data presented a slightly different three factor solution. The application of Cronbach's alpha to the ERB measures found most of the measures had to be dropped before achieving an acceptable value. The remaining three measures are the three general behavior items (see Table 1). The alpha value for the pre-course data was 0.781 and 0.847 for the post-course data. This result is reasonable if we look at the nature of the questions for ERB. The ERB scale is an example of a formative rather than a reflective measure. Reflective measures all reflect the underlying construct and therefore tend to be one dimensional. Formative measures when combined form the construct. Thus items such as recycling or turning off air conditioners form the construct of environmentally responsible behavior. Formative measures are multidimensional and cannot be treated as a combined scale [41]. The three item combined ERB scale was compared using ANOVA. The results were not significant, with an $\mathrm{F}$ value 1.882 and significance level of 0.171 .

\section{Exploratory Analysis: Examining the Impact of Attitudes on Behavior}

Since this project is an exploratory study, it is appropriate to apply an inductive research approach. Inductive analysis is a bottom up process that involves reviewing data, looking for patterns, and then conducting some type of confirmatory analysis [42]. This project is a form of intervention intended to increase environmentally sustainable behavior. Based on the data collected this did not happen. There were no significant findings to indicate this intervention was effective. This is consistent with a published review of intervention techniques intended to diminish energy use that found the success of these interventions was mixed at best [43]. Examples of antecedent interventions include commitment, goal setting, providing information, and modeling. Examples of consequence interventions are feedback and rewards. This review found that interventions involving commitment and goal setting were successful, especially when combined with other techniques. Providing information alone was shown to have poor results. Providing economic incentives was found to be effective, but the impact often disappeared once the incentive was no longer provided [43].

What methods can be employed to reduce US energy consumption? One insight may come from the domain of public health, which has conducted extensive research identifying factors that influence positive change away from self-destructive behavior such as smoking cigarettes or drug use. Clinical psychologists and other health professionals have found that if individuals express ambivalent attitudes towards self-destructive behavior, its consequences, or steps needed to alter that behavior, this ambivalence acts as a powerful impediment to change [44]. While people whose behavior can damage their health often agree that change is important, they show substantial resistance when called upon to modify their lifestyle. An important finding is that, paradoxically, exposure to increasingly negative consequences can prevent change by immobilizing the person, or even make the behavior worse. Instead, "constructive behavior change seems to arise when the person connects it with something of intrinsic value, something important, something cherished" [44].

There is a strong consensus that solving environmental problems requires behavioral changes [43], but efforts conducted to date have not been effective. The domain of public health has intensely studied techniques that change behavior, especially for addictions to drugs, alcohol, or smoking. An argument can be made that climate change is a public health issue that will affect the health of everyone on the planet. Since environmental sustainability will depend on changes in individual behavior, the perspective of the public health field is quite relevant. Even the language used by President Bush, who in his 2006 State of the Union Address stated that "America is addicted to oil" [45], reinforces the validity 
of analyzing energy consumption behavior change from the public health perspective.

A prominent theory of behavior change is the Transtheoretical Model of Intentional Human Behavior Change (TTM) [46]. TTM provides a framework for understanding the process of change by identifying specific stages people pass through as they change a behavior. TTM identifies the first stage as the precontemplation stage, where the person is not currently considering a change in their behavior. This is followed by the contemplation stage, where the person begins to seriously evaluate the factors for and against change. Next the individual enters the preparation stage, where both planning and a firm commitment to change take place. If these initial analytical and planning stages are successful, the person moves into the action stage and initiates the behavior change. This is followed by the maintenance stage, where the person reflects on the impact of their behavior changes, and takes steps to continue long term change in behavior [46].

While it may seem outrageous to compare the behavior of people who do not recycle with those who are addicted to drugs, the underlying issues of ambivalence and obstacles to change are quite similar. The pivotal role of ambivalence with respect to sustainability was the main finding of the inductive analysis of the project's data. Developing techniques to combat ambivalence, and avoiding anxiety provoking methods when discussing climate change were found to be the most effective way to encourage progress in sustainable behavior.

To document the ambivalence connected to anxiety and pro-environmental behavior, the subjects were clustered into three groups: students with a high degree of anxiety about sustainability and climate change (labeled the Anxiety cluster); students who are concerned with addressing and finding solutions to sustainability issues (labeled the Agency cluster); and students who reject or deny that climate change is a problem (labeled the Denial cluster). The clusters were identified these measures taken from the NEP:

- Denial: "The so-called ecological crisis facing humankind has been greatly exaggerated"

- Anxiety: "When humans interfere with nature it often produces disastrous consequences"

- Agency: "We must take stronger measures to conserve our nation's resources"

Using the measures as proxies for attitudes affected the makeup of the combined NEP scale. The removal of these measures decreased the number of items in the combined NEP scale from seven to four. The remaining questions address intended pro-environmental behavior (see Table 1). The reliability for the four item NEP scale is a Cronbach's alpha value of 0.651 for the pre-course results and 0.762 for the post course results.

Table 5 presents an overview of the three clusters, and their impact on the pre- and post-survey results. For each cluster, the table includes a definition, the specific measure used for that cluster, a representative student comment, the pre- and post-course statistics, and the pre- and post-course correlations. Because this study followed an inductive approach, the selection of measures to reflect each attitude was done on a post-hoc basis. The weakness of this approach is that the measures selected are indirect indications of the attitude. In addition, a single measure is used rather than a fully developed scale. Despite these methodological issues, this analysis provides some intriguing results.

\subsection{Analyzing the Impact of the Three Clusters}

The values for each cluster was compared to the combined three item ERB scale and four item NEP scale using Pearson's R. The results are summarized in Table 6. Looking at the pre-course data, both the Denial and Agency cluster have higher $\mathrm{R}$ values compared to the Anxiety cluster. Comparing the pre-course to the post-course results, the clusters move in different directions. The Denial cluster dramatically drops in influence, going from two significant $\mathrm{R}$ values of -0.402 and -0.286 in the pre-course data to a much weaker $\mathrm{R}$ value of -0.166 for the NEP scale and no significant findings for the ERB scale. The Agency cluster increases its $\mathrm{R}$ value for both scales. The Anxiety cluster goes from pre-course R values of 0.204 and 0.163 for the NEP and ERB scales to values of 0.313 and 0.344 for the postcourse data.

Comparing pre- and post-course for each measure individually confirms a change in the interaction of the three clusters. In the pre-course survey, the Denial measure is the strongest predictor of attitudes and behavior with 11 significant results, followed by Agency with seven significant results, and the Anxiety measure with four. In the post-course survey, the Agency measure is the strongest with eight significant results, followed by Anxiety with four and Denial with four.

In the pre-course survey, the strongest result for the Denial measure with a Pearson's R value of -0.364 and a p value $<0.0001$ is this statement: "I would support a tax on carbon emissions." The strongest result for the Agency measure was a Pearson's R value of 0.448 and a $\mathrm{p}$ value $<0.0001$ for this statement: "I would be willing to pay more in taxes to support renewable energy projects."

In the pre-course survey, the Anxiety measure was a weak predictor of pro-environmental attitudes and behavior. This is surprising since it has a relatively high mean (4.876 out of 7). The Anxiety measure has significant relationships with four measures, with low $\mathrm{R}$ values 
Table 5. Summary of findings regarding denial, agency, and anxiety clusters.

\begin{tabular}{|c|c|c|c|}
\hline & Denial & Agency & Anxiety \\
\hline Definition & $\begin{array}{l}\text { Individual denies climate change } \\
\text { is “real”, and has no intention to } \\
\text { change consumption behavior }\end{array}$ & $\begin{array}{l}\text { Individual recognizes climate } \\
\text { change as an urgent issue, believes } \\
\text { their own actions can contribute to } \\
\text { a solution }\end{array}$ & $\begin{array}{l}\text { Individual expresses concern that cli- } \\
\text { mate change/energy shortages will lead } \\
\text { to chaos and global destruction }\end{array}$ \\
\hline $\begin{array}{l}\text { Survey Measure } \\
(1=\mathrm{SD}, 7=\mathrm{SA})\end{array}$ & $\begin{array}{l}\text { "The so-called ecological crisis } \\
\text { facing humankind has been } \\
\text { greatly exaggerated." }\end{array}$ & $\begin{array}{l}\text { "We must take stronger measures to } \\
\text { conserve our nation's resources." }\end{array}$ & $\begin{array}{l}\text { "When humans interfere with nature it } \\
\text { often produces disastrous conse- } \\
\text { quences." }\end{array}$ \\
\hline $\begin{array}{l}\text { Affect/Attitude towards } \\
\text { sustainability }\end{array}$ & $\begin{array}{l}\text { "Sustainability is important for } \\
\text { businesses to do for the future and } \\
\text { I agree with it... It just doesn't } \\
\text { play a part in my life." }\end{array}$ & $\begin{array}{l}\text { "I think everyone has a responsibil- } \\
\text { ity to help keep our environment } \\
\text { livable. The impact of sustainability } \\
\text { has a dramatic impact on my fture." }\end{array}$ & $\begin{array}{l}\text { "The Earth I live on could potentially } \\
\text { become a wasteland if humans do not } \\
\text { change their attitude about sustainabil- } \\
\text { ity." }\end{array}$ \\
\hline Pre-course values $N=188$ & Mean $=3.016$, S.D. $=1.374$ & Mean $=5.793$, S.D. $=1.272$ & Mean $=4.876$, S.D. $=1.604$ \\
\hline $\begin{array}{l}\text { Pre-course correlations } \\
\text { (with } 14 \text { measures) }\end{array}$ & $\begin{array}{l}11 \text { Sig. Corr. in total } \\
\text { R values relatively high }\end{array}$ & $\begin{array}{l}7 \text { Sig. Corr. in total } \\
\text { R values moderate }\end{array}$ & $\begin{array}{l}4 \text { Sig. Corr. in total } \\
\text { R values low }\end{array}$ \\
\hline $\begin{array}{l}\text { Pre-course sustainability } \\
\text { behavior }\end{array}$ & $\begin{array}{l}\text { Ignore the issue; } \\
\text { Won't recycle; } \\
\text { Won't support carbon tax or fee } \\
\text { for disposable bags }\end{array}$ & $\begin{array}{l}\text { Does recycle; } \\
\text { Strong support for carbon tax and } \\
\text { funding for alternative energy }\end{array}$ & $\begin{array}{l}\text { Will discuss sustainability issues with } \\
\text { friends; } \\
\text { Not committed to recycling; weakly } \\
\text { supports carbon tax and government } \\
\text { funding of alternative energy }\end{array}$ \\
\hline $\begin{array}{c}\text { Post-course values } \\
\qquad N=147\end{array}$ & Mean $=3.143$, S.D. $=1.562$ & Mean $=5.945$, S.D. $=1.374$ & Mean $=5.007$, S.D. $=1.595$ \\
\hline $\begin{array}{l}\text { Post-course correlations } \\
\text { (with } 14 \text { measures) }\end{array}$ & $\begin{array}{l}4 \text { Sig. Corr. in total } \\
\text { R values decrease from pre-course } \\
\text { results }\end{array}$ & $\begin{array}{c}8 \text { Sig. Corr. in total } \\
\text { R values increase from pre-course } \\
\text { results }\end{array}$ & $\begin{array}{l}7 \text { Sig. Corr. in total } \\
\text { R values increase from pre-course results }\end{array}$ \\
\hline $\begin{array}{l}\text { Post-course sustainability } \\
\text { behavior }\end{array}$ & $\begin{array}{l}\text { Power of this attitude is greatly } \\
\text { reduced to } 4 \text { sig. corr. down from } \\
11 \text { sig. corr. }\end{array}$ & $\begin{array}{l}\text { Increase in corr. From } 7 \text { to } 8 \text {; } \\
\text { strongest predictor of commitment } \\
\text { to sustainability }\end{array}$ & $\begin{array}{l}\text { Increase in corr. From } 4 \text { to } 7 \text {, more } \\
\text { support for broader measures (like car- } \\
\text { bon tax) but still ambivalent about recy- } \\
\text { cling }\end{array}$ \\
\hline
\end{tabular}

Table 6. Summary of pearson's $R$ comparing clusters to the combined NEP and ERB.

\begin{tabular}{|c|c|c|c|c|c|c|c|}
\hline Pre & & Combined NEP & Combined ERB & Post & & Combined NEP & Combined ERB \\
\hline \multirow{3}{*}{ Denial } & $\mathrm{R}$ & $-0.402 * * *$ & $-0.286^{* * *}$ & \multirow{3}{*}{ Denial } & $\mathrm{R}$ & $-0.166^{*}$ & -0.037 \\
\hline & Sig. & 0.000 & 0.000 & & Sig. & 0.046 & 0.659 \\
\hline & $\mathrm{N}$ & 183 & 185 & & $\mathrm{~N}$ & 145 & 146 \\
\hline \multirow{3}{*}{ Agency } & $\mathrm{R}$ & $0.446^{* * *}$ & $0.226^{* *}$ & \multirow{3}{*}{ Agency } & $\mathrm{R}$ & $0.466 * * *$ & $0.294 * * *$ \\
\hline & Sig. & 0.000 & 0.002 & & Sig. & 0.000 & 0.000 \\
\hline & $\mathrm{N}$ & 180 & 182 & & $\mathrm{~N}$ & 144 & 145 \\
\hline \multirow{3}{*}{ Anxiety } & $\mathrm{R}$ & $0.204^{* *}$ & $0.163^{*}$ & \multirow{3}{*}{ Anxiety } & $\mathrm{R}$ & $0.313^{* * *}$ & $0.344^{* * *}$ \\
\hline & Sig. & 0.006 & 0.027 & & Sig. & 0.000 & 0.000 \\
\hline & $\mathrm{N}$ & 182 & 184 & & $\mathrm{~N}$ & 144 & 145 \\
\hline
\end{tabular}

$* \mathrm{p}<0.05, * * \mathrm{p}<0.01, * * * \mathrm{p}<0.001$

ranging from 0.14 to 0.16 .

In the post-course survey, there is a steep decline in the influence of the Denial measure, with a drop from 11 significant correlations pre-course to four in the postcourse survey. For the Anxiety measure, there is an increase from four to seven significant results.

The influence of the Agency measure increases from seven significant correlations to eight. The $\mathrm{R}$ values for these correlations are relatively high, with an $\mathrm{R}$ value of 0.439 and a p value $<0.001$ supporting a carbon tax, and an $\mathrm{R}$ value of 0.428 and a $\mathrm{p}$ value $<0.001$ supporting renewable energy projects.

\subsection{Analysis of Qualitative Data with Respect to the Three Clusters}

The survey included free form questions where students could make comments about the course material. Students were asked to reflect on "the impact of sustainability issues on your future.” Those students expressing anxiety typically did not specify actions to mitigate en- 
ergy consumption patterns. In contrast, those students who described the problem in serious but non-emotional terms were more likely to suggest remedies they intended to pursue.

Here is a sample of comments that reflected a high level of anxiety, but notably did not include any solutions or suggested actions:

- I fear that we as a country will not conserve our resources and the majority of them will be used up before I die.

- If we are not able to sustain our current lifestyle with new sources on energy, we will probably be reduced back to medieval times.

- $\quad$ The planet will die.

In contrasts, student comments that discussed sustainability in more dispassionate terms included practical suggestions to improve the situation:

- $\quad$ These issues are very important and should not be overlooked. Everyone should at least try and recycle.

- I think that everyone needs to take responsibility for their own actions. The world depends on it.

- We must be able to conserve resources that we have today and learn to use new ones.

The disruptive influence of the Anxiety cluster was also evident in the tone and focus of class discussions. Students bring with them a long exposure to Hollywood disaster movies, a staple of mainstream entertainment for decades. Many feature extreme computer generated special effect sequences depicting global catastrophe, where buildings, cities, and populations are wiped out. The emotional impact of these Hollywood spectacles has resonated with the discussion of climate change. In presenting the energy literacy materials, it required a conscious effort on the part of the instructor to steer discussion towards a rational analysis of sustainability, and away from fantastic speculations of global collapse and destruction.

Between Hollywood disaster movies and alarmist coverage in the mass media, themes of fear, anxiety, and pending disaster dominate discussions of climate change. These themes generate of lot of attention, but trigger emotional shutdown rather than engagement and concerted action. Media critics have argued that the "selling" of fear leads to disassociation and emotional withdrawal [47]. Environmentalists warn that scare-mongering and fanciful predictions interfere with the necessary considerations of structural changes [48]. With respect to how these themes influence the students in this study, the instructor found that any content touching on ecological disaster distracted students from a rational discussion of policy, and even worse, moved their attention away from a willingness to change energy use behavior.

\section{Limitations}

The results described here come from an exploratory study and as such should be interpreted in consideration of the following limitations. The three clusters-Denial, Anxiety and Agency-are captured with a single measure, rather than a fully validated scale. In addition, the results come from one instructor at one university. There was also difficulty ensuring the full participation of all students in both the pre-course and the post-course survey. The number of students taking the pre-course survey is more than one third higher than those taking the postcourse survey. Also, the survey questions administered are not specifically connected to the issue of energy literacy or specific materials from the course. Therefore a connection between the results and the course materials can only be inferred.

It is also important to note that correlation is not the same as causation, so these results do not prove a connection between the course material and the results. For instance, there is a large time gap between the administration of the pre- and post-course surveys. Other factors and events could have influenced these results, especially since sustainability issues are the topic of frequent media coverage and policy discussion.

\section{Summary and Conclusions}

Environmental sustainability is a prominent public concern. A large factor in the strain on the global environment is the world's dependence on fossil fuels. This dependence places stress on the environment in two distinct ways. One is that the supply of fossil fuels is finite, and there are diminishing expectations that the current energy infrastructure will be able to match supply with future demand [5,30]. Secondly, the use of fossil fuels for energy causes carbon emissions linked to climate change [49].

Since US energy consumption is a reflection of individual energy consumption choices, any actions by US consumers to embrace sustainability will greatly ease the strain on the environment. In the past, extreme price increases have reduced US energy consumption. But trying to solve this problem by raising the cost of energy can cause severe economic disruptions and hardships among many citizens. There must be a commitment to noneconomic methods for reducing energy use.

Therefore, a concerted effort is needed to change the US culture to an emphasis on sustainability. This paper describes curricula materials that introduced energy literacy as a topic for an undergraduate course. Energy literacy is a construct that combines conceptual fluency with the economic and social components of energy use, along with the belief that an increase in energy literacy 
will result in more sustainable energy practices. The primary findings presented here, based on an analysis of student sustainability attitudes and behaviors, is that discussions of sustainability with disaster themes can trigger anxiety that interferes with the goal of encouraging sustainability. In contrast, materials that focused on the pragmatic necessity and concrete benefits had a more positive impact on promoting pro-environmental behavior.

The findings of this project are promising, and provide motivation to create materials that mitigate the negative effect that anxiety provoking discussions have on improvement in sustainability. Future research includes the development of scales to measure the three clusters identified-Denial, Anxiety and Agency. Additional measures are needed to specify the relationship between the course materials and the results. There are also efforts to make these materials available for use by other instructors and test their effect at other institutions [50]. The need to change US consumption patterns is critical, and any evidence that suggests progress must be pursued vigorously.

Sustainability has gained significant public and government attention, and many colleges are recognized for their greening efforts. In many respects, the academy is expected to be a leader in efforts to improve sustainability. The finding of this project suggest that the development of materials that support energy literacy, with an emphasis on pragmatic solutions and an avoidance of disaster themes, can make a significant contribution in changing US cultural attitudes towards sustainability.

\section{Acknowledgements}

The author would like to acknowledge the helpful feedback and suggestions of the anonymous reviewer.

\section{REFERENCES}

[1] R. Watson, M. C. Boudreau and A. J. Chen, "Information Systems and Environmentally Sustainable Development: Energy Informatics and New Directions for the IS Community," Management Information Systems Quarterly, Vol. 34, No. 1, 2010, pp. 23-38.

[2] T. A. Jenkinlow, J. Webster and L. McShanea, “An Agenda for 'Green' Information Technology and Systems Research,” Information and Organization, Vol. 21, No. 1, 2011, pp. 17-40. doi:10.1016/j.infoandorg.2010.09.003

[3] N. Melville, "Information Systems Innovation for Environmental Sustainability," Management Information Systems Quarterly, Vol. 34, No. 1, 2010, pp. 1-21.

[4] H. Hasan and C. Dwyer, "Was the Copenhagen Summit Doomed from the Start? Some Insights from Green IS research," Americas Conference on Information Systems 2010 Proceeding, Lima, 2010, p. 67.
[5] V. Smil, "Energy at the Crossroads," OECD Global Science Forum Conference, Paris, 17-18 May 2006.

[6] EIA, “The Energy Information Administration,” 2011. http://www.eia.doe.gov/

[7] S. Swartz and S. Oster, "China Tops U.S. in Energy Use," 2011.

http://online.wsj.com/article/SB100014240527487037205 04575376712353150310.html

[8] WikiPedia, "List of Countries by Energy Consumption Per Capita,” 2011.

http://en.wikipedia.org/wiki/List_of_countries_by_energy _consumption_per_capita

[9] IEA, “World Energy Outlook 2009,” International Energy Agency, Paris, 2009.

[10] H. S. Matthews, C. T. Hendrickson and C. L. Weber, "The Importance of Carbon Footprint Estimation Boundaries," Environmental Science \& Technology, Vol. 42, No. 16, 2008, pp. 5839-5842. doi:10.1021/es703112w

[11] D. Yergin, “The Prize: The Epic Quest for Oil, Money, and Power,” Free Press, New York, 1991.

[12] J. Diamond, "Collapse: How Societies Choose to Fail or Succeed,” Penguin Books, New York, 2005.

[13] A. Revkin, "Smil on Hummers, Hondas, Meat, Heat," The New York Times, New York, 19 October 2009.

[14] K. S. Deffeyes, "Beyond Oil: The View From Hubbert's Peak.” Hill and Wang, New York, 2005.

[15] NYMEX, “Light Sweet Crude Oil Futures Contract Specifications," 2011.

http://www.cmegroup.com/trading/energy/crude-oil/light -sweet-crude_contract_specifications.html

[16] A. Ward, "REC Predicts Bright Future for Solar Energy,” 2011. http://www.ft.com/cms/s/0/38f2c9fe-b227-11e0-9d80-00 144feabdc0.html\#axzz1ShA8S5Ju

[17] G. Metcalf, "Designing a Carbon Tax to Reduce US Greenhouse Gas Emissions,” Review of Environmental Economics and Policy, Vol. 3, No. 1, 2009, pp. 63-83. doi:10.1093/reep/ren015

[18] L. H. Barrow and J. T. Morrisey, "Energy Literacy of Ninth-Grade Students: A Comparison between Maine and New Brunswick," Journal of Environmental Education, Vol. 20, No. 2, 1989, pp. 22-25. doi:10.1080/00958964.1989.9943027

[19] J. DeWaters and S. Powers, "Energy Literacy among Middle and High School Youth," The 38th ASEE/IEEE Frontiers in Education Conference, Sarasota, 2008, pp. 6-11.

[20] UNESCO, “The Plurality of Literacy and its Implications for Policies and Programmes," UNESCO Education Sector, Paris, 2004.

[21] L. Snyder, A. V. Aho, M. Linn, A. Packer, A. Tucker, J. D. Ullman and A. Van Dam, "Being Fluent with Information Technology,” National Academy Press, Washington, D.C., 1999.

[22] E. A. Gomez and M. Turoff, "Community Crisis Response Teams: Leveraging Local Resources through ICT E- 
Readiness," The 40th Hawaii International Conference on System Sciences, Hawaii, 2007.

[23] J. Meyer and C. Dwyer, "Improving Quantitative Reasoning Through Analysis of News Stories," International Journal of Learning, Vol. 12, No. 6, 2006, pp. 165-174.

[24] P. Berthon, J. Hulbert and L. Pitt, "Consuming Technogy: Why Marketers Get It Wrong," California Management Review, Vol. 48, No. 1. 2005, pp. 110-128.

[25] R. Watson, M. C. Boudreau, A. Chen and M. Huber, "Green IS: Building Sustainable Business Practices," Information Systems, Atlanta, 2007.

[26] D. Lockton, D. J. Harrison and N. A. Stanton, "Making the User More Efficient: Design for Sustainable Behaviour,” Brunel University Research Archive, Brunel, 2008.

[27] ACUPCC, “American College and University Presidents' Climate Commitment,” 2011. http://www.presidentsclimatecommitment.org/

[28] EIA, “The Energy Information Administration," 2009. http://www.eia.doe.gov/

[29] J. Mouawad, "Amid High Oil Prices, Danger Signs in Production,” The New York Times, New York, 28 Apil 2008.

[30] R. L. Hirsch, "The Inevitable Peaking of World Oil Production," 2009. http://www.acus.org/docs/051007-Hirsch_World_Oil_Pro duction.pdf

[31] M. Fishbein and I. Ajzen, "Belief, Attitude, Intention and Behavior: An Introduction to Theory and Research," Addison-Wesley Publishing Company, New York, 1975.

[32] I. Ajzen, “The Theory of Planned Behavior," Organizational Behavior and Human Decision Processes, Vol. 50, No. 2, 1991, pp. 179-211. doi:10.1016/0749-5978(91)90020-T

[33] C. Mobley, W. M. Vagias and S. L. DeWard, "Exploring Additional Determinants of Environmentally Responsible Behavior: The Influence of Environmental Literature and Environmental Attitudes," Environment and Behavior, Vol. 42, No. 4, 2009, pp. 420-447. doi:10.1177/0013916508325002

[34] M. T. Dishawa and D. M. Strong, "Supporting Software Maintenance with Software Engineering Tools: A Computed Task-Technology Fit Analysis,” Journal of Systems and Software, Vol. 44, No.2, 1998, pp. 107-120. doi:10.1016/S0164-1212(98)10048-1

[35] M. Cordano, S. A. Welcomer and R. F. Scherer, “An Analysis of the Predictive Validity of the New Ecological Paradigm Scale," Journal of Environmental Education, Vol. 34, No. 3, 2003, pp. 22-28. doi:10.1080/00958960309603490

[36] R. Dunlap, K. V. Liere, A. Mertig and R. E. Jones, "Measuring Endorsement of the New Ecological Paradigm: A
Revised NEP Scale,” Journal of Social Issues, Vol. 56, No. 3, 2000, pp. 425-442. doi:10.1111/0022-4537.00176

[37] J. J. Vaske and K. C. Kobrin, "Place Attachment and Environmentally Responsible Behavior," Journal of Environmental Education, Vol. 32, No. 4, 2001, pp. 16-21. doi:10.1080/00958960109598658

[38] N. J. Smith-Sebasto and A. D’Costa, “Designing a LikertType Scale to Predict Environmentally Responsible Behavior in Undergraduate Students: A Multistep Process,” Journal of Environmental Education, Vol. 27, No. 1, 1995, pp. 14-20. doi:10.1080/00958964.1995.9941967

[39] S. Kaplan, "Human Nature and Environmentally Responsible Behavior,” Journal of Social Issues, Vol. 56, No. 3, 2000, pp. 491-508. doi:10.1111/0022-4537.00180

[40] J. Nunnally, "Psychometric Theory," Mc-Graw-Hill, New York, 1967.

[41] S. Petter, D. W. Straub and A. Rai, "Specifying Formative Constructs in Information Systems Research,” Management Information Systems Quarterly, Vol. 31, No. 4, 2007, pp. 623-656.

[42] H. R. Bernard, “Social Research Methods,” Sage Publications Inc., Thousand Oaks, 2000.

[43] W. Abrahamse, L. Steg, C. Vlek and T. Rothengatter, “A Review of Intervention Studies Aimed at Household Energy Conservation,” Journal of Environmental Psychology, Vol. 25, No. 3, 2005, pp. 273-291. doi:10.1016/j.jenvp.2005.08.002

[44] W. R. Miller and S. Rollnick, "Motivational Interviewing: Preparing People for Change,” 2nd Edition, The Guilford Press, New York, 2002.

[45] G. Bush, "State of the Union Address," 2011. http://www.washingtonpost.com/wp-dyn/content/article/2 006/01/31/AR2006013101468.html

[46] C. C. DiClemente and J. Prochaska, "Toward a Comprehensive, Transtheoretical Model of Change: Stages of Change and Addictive Behaviours,” 2nd Edition, Plenum Press, New York, 1998.

[47] S. D. Moeller, "Compassion Fatigue: How the Media Sell Disease, Famine, War and Death,” Routledge, New York, 1999.

[48] S. Fankhauser, "Valuing Climate Change: The Economics of the Greenhouse,” Earthscan Publications, London, 1995.

[49] A. McMichael, R. Woodruff and S. Hales, "Climate Change and Human Health: Present and Future Risks," The Lancet, Vol. 367, No. 9513, 2006, pp. 859-869. doi:10.1016/S0140-6736(06)68079-3

[50] C. Dwyer and E. A. Gomez, "Sustainability Course Modules for Information Systems and Interdisciplinary Courses," America's Conference on Information Systems, San Francisco, 2009. 


\section{Appendix}

These materials were included as coursework for an Introduction to Computing class, taught in multiple sections beginning in Spring 2008. Students are mostly first year or sophomore level. The curriculum material introduces sustainability issues in three parts. The first part consists of data analysis exercises using a spreadsheet (Excel). The second part contains sustainability reading assignments and online discussion. The third part is the creation of a group Web site presenting a sustainability case study of a target company. Links to the assignment templates and instructions can be found at http://csis. pace.edu/ dwyer/EnergyLiteracy/.

\section{Data Analysis Exercises}

The objective of these data analysis assignments are:

- $\quad$ expose students to "real world" data sources

- $\quad$ apply data analysis methods to understand information about a certain context

- be able to draw conclusions based on the results of the data analysis

All of these assignments use data publicly available from the US Energy Information Agency (EIA-http:// www.eia.doe.gov/). Using "real world data” exposes students to more complex data sets than are typically included in classroom assignments.

Each assignment guides students through a specific data analysis process. In class, students are asked to describe the findings of their analysis, and draw conclusions on their findings. Using this process with increasingly complex assignments, students are exposed to more complicated problems, and are asked to provide insights on multi-layered problems that do not have a simple "yes no" answer.

\subsection{Assignment One: US Oil Production vs. Consumption, 1980-2007}

In this first exercise, students begin with a spreadsheet loaded with data values for US oil production and consumption from 1980-2007. Their assignment is to use Excel formulas and functions to calculate the amount of imports needed each year, the percentage of imports compared to consumption, the decrease in US oil production, and the increase in oil consumption from the previous year.

After completing this assignment, students are able to apply basic Excel formulas and functions to a small data set. Students are also asked in class to review the findings of the data analysis and draw conclusions about the pattern of US oil production versus consumption. Students are able to summarize the data, and show a pattern of decreasing oil production along with increasing consumption. Some students commented that the data show them their perception of US energy use was inaccurate.

\subsection{Assignment Two: Impact of Fuel Efficiency \\ Standards on Fuel Use and Carbon Emissions}

In 2008 the US Congress passed legislation that will require light vehicles to meet a standard of 35 miles per gallon (MPG) as of 2020. This assignment provides a data analysis of the impact of the new legislation. Students first collect data on the current top selling vehicles, calculate their average fuel use and carbon emissions. Then they compare the impact of requiring $35 \mathrm{MPG}$ as of 2020, in terms of fuel consumed, cost, and carbon emissions. Carbon emissions are calculated on the basis of 20 pounds of $\mathrm{CO}_{2}$ produced for every gallon of gas consumed.

In this assignment, students gain experience collecting data identifying the five best selling light vehicles, along with their MPG rating. They gain experience conducting a forecasting analysis of the impact of legislation.

During class discussion, students are able to describe the expected impact of the legislation. Since some of the best selling vehicles already exceed 35 MPG, the new standard will have a minimal impact. Students also comment on the $\mathrm{CO}_{2}$ emissions. Most are unaware of the amount of $\mathrm{CO}_{2}$ produced by the routine use of cars.

\subsection{Assignment Three: Relationship between Fuel Efficiency Standards and US Need for Imported Oil}

This assignment carries out an analysis of the relationship between the average fuel efficiency of US vehicles and the amount of oil the US is required to import to make up for inadequate domestic production. In 2007, the US imported nearly five billion barrels of oil.

This assignment carries out a very simple analysis of the impact of improved MPG on imports. First, it assumes all the imported oil is used for transportation. Secondly, it assumes one number for each MPG alternative, even though cars remain on the road for about ten years and it would be impossible to bring up all vehicles at once to a higher standard. It also makes the assumption that the amount of miles driven would remain constant. However given these limitations, this analysis does show how improving vehicle MPG can have a direct impact on oil imports.

The analysis is as follows. Every barrel of oil when refined produces 19.5 gallons of gasoline. Given the average MPG of US vehicles of 20 MPG, in 2007 imported oil was used to drive nearly two trillion miles. Keeping the number of miles driven as a constant, an analysis was conducted to see how improved MPG could reduce oil imports. An analysis was conducted for the 2020 CAFÉ standards of 35 MPG (set by US legislation), an MPG of 48.4 for current hybrid technology, an MPG of 59 MPG 
by European diesel engines, and an estimated MPG of 93.50 for a plug-in hybrid under development by Google. Results ranged from a drop in imports of $43 \%$ resulting from 2020 CAFÉ standards, to a drop of $79 \%$ from the plug-in hybrid.

\subsection{Capstone Data Analysis Project: Team Analysis of Energy Forecast Data}

This in class assignment is the capstone exercise for the energy data analysis module. Students are paired in teams, and given a spreadsheet that is the official US forecast of energy production and consumption from 2007 through 2030. Students are given a series of questions, and are asked to design a chart that answers the questions, and write a paragraph explaining what their chart illustrates, and what conclusions can be drawn from the chart.

Here is the Scenario and the questions each student team must answer:

You have been hired to work as student interns for Goldman Sachs, to assist them in the preparation of global investment recommendations for the next 20 years. One factor that will influence future conditions is the degree of dependence the US has on imported oil. The more oil the US has to import, the more vulnerable US companies will be to disruptions in energy sources, which may weaken US companies. You are being asked to prepare a report on the state of US energy independence, based on official projections made by the US Energy Information Agency (EIA). In your report you will prepare answers to the questions listed below. The goal is to present a written report that answers the questions using charts.

1) What will the status of energy independence projected to be in 2020? In 2030? Create a chart that demonstrates your answer.

2) What is expected to be the most successful source of alternative fuels during the decade from 2020 to 2030 ? Produce a chart that demonstrates your answer.

3) How is liquid fuel consumption expected to change from 2006 to 2030 in each of the sectors listed (residential, industrial, transportation, electric power)?

This assignment asks students to evaluate US energy independence based on official projections from the EIA through 2030. This is a challenging assignment for these students for several reasons. First of all, the forecast spreadsheet from the EIA is an official document, and is extremely complex, with many different categories of consumption, production, and fuel types. Many columns have footnotes explaining technical differences between grades of fuel students are unfamiliar with. In addition, there is no row or column anywhere on the spreadsheet with the words "energy independence”. Instead, the stu- dents must define what that means, and then select the right data on the spreadsheet that will display the answer.

A second challenge to this assignment is that the students are required to produce a chart to illustrate their answer. This is a complex task which requires them to construct a visual representation of data. Many find this to be difficult, and frankly their first versions of charts look awful. Only after they identify the data required, and clearly describe the relationship they are trying to represent, are they able to produce a chart that makes sense.

\section{Readings and Discussion Postings}

In parallel with the data analysis exercises, students were assigned a weekly reading and discussion exercise. These readings provided a context to energy use, and provided the students with a framework with which to interpret the findings of their data analysis.

\subsection{Week One}

Reading Assignment: National Geographic 6-08, “Tapped Out”.

Discussion questions:

1) This week's assigned reading is Tapped Out, published in National Geographic. The article talks about discovery rates, and how they can be used to forecast future production trends. What is the connection between discovery rates and production? And what trends do discovery rates predict for production?

2) This article begins with a discussion of an analysis undertaken by Sadad Al Husseini, a Saudi oil geologist. Al Husseini was skeptical of forecasts for future oil production. He decided to carry out a quantitative data analysis to determine whether these forecasts were realistic. What did he find out? What method did he apply to collect information and reach his conclusion?

3) Do you agree or disagree with the conclusions of $\mathrm{Al}$ Husseini? What weakness or problems do you see from his method?

\subsection{Week Two}

Reading Assignment: NY Times 4-23-08, “Europe Turns Back to Coal, Raising Climate Fears”.

Discussion questions:

1) Many countries are turning to coal for electricity. Why? What are the advantages of using coal?

2) What does the article say about "clean coal"? What is the biggest problem caused by burning more coal?

3) Are oil companies greedy when they raise the price of oil? Argue that this is TRUE, and support your argument with facts (include reference or link to sources).

4) Are oil companies greedy when they raise the price of oil? Argue that this is FALSE, and support your argument with facts (include reference or link to sources). 


\subsection{Week Three}

Reading Assignment: The Atlantic Council 10 - 05, "The Inevitable Peaking of World Oil Production”.

Discussion questions:

1) Who is the author of this week's assigned readings? What is his background? What are his qualifications on this topic? What organization published this report? What type of work does this organization do?

2) What is meant by "peaking"? What is the difference between peaking versus "running out of oil"?

3) The paper talks about a liquid fuels crisis. What does that mean? What industries are vulnerable to a liquid fuels crisis?

\subsection{Week Four}

Assignment: Watch the video podcast "Winning the oil endgame" (available on iTunes).

Discussion questions:

1) The presenter says we don't necessarily need oil, but that we want the service it provides. What does he mean?

2) The presenter mentions that the Pentagon funded the study that led to the book "Winning the oil endgame". According to the presenter, why does the military have a motivation to study how to eliminate the use of oil?

3) What strategies does the presenter suggest to increase the efficiency of cars?

4) What do you think of the validity of the presentation? Did his proposal seem to be a good idea? Why or why not?

\subsection{Week Five}

Reading Assignment: "Green IS: Building Sustainable Business Practices”, by Marie-Claude Boudreau, Adela Chen, and Mark Huber.

Discussion questions:

1) The authors make a distinction between Green IT and Green IS. Define what is meant by Green IT. Define what is meant by Green IS. How are they different?

2) Velib is an innovative bicycle rental program implemented in Paris, France. It is described in the article beginning on page 6 . Do you think this would work in NYC? Why or why not?

3) The paper identifies three types of sustainability goals: pollution prevention, product stewardship, and clean technology. Define one of these goals, and provide a specific example of a company meeting one of these goals (include a link to a web site or article describing the effort).

4) The paper identifies three levels in which a sus- tainability goal may apply: individual, organizational, and societal. Define the difference between individual, organizational and societal. Give an example of how an individual (such as yourself) can meet a sustainability goal, how an organization can do so, and how society at large can do so.

5) The paper identifies individual, organizational, and societal levels for sustainability efforts. Is one more important than the other? Rank these levels, and include an explanation for your ranking.

\section{Group Project-Corporate Sustainability Case Study}

As a capstone to the course, student teams produced a group web page that presented a sustainability analysis of a particular company. The site contained the following sections:

Main page: Home page for your site, with a menu to control to the other sections of the web site.

Overview of target company: This page presented a summary of the company being analyzed. The analysis included a discussion of strengths, weaknesses, leadership issues, and any positive or negative ethical/moral issues being raised by the company and/or the media or government; an overview of the industry which the company is in; and an overall view of sustainability within the industry as a whole (as seen from both internal and external evaluations).

Examples of sustainability practices: This page summarizes sustainability business practices the target company has in place, or has announced plans to put into place. The page must include at least two examples of sustainability efforts in this section. In your description of these practices, you must refer to the Framework of Sustainability Options (from the "Green" IS reading), and identify what practice the company is engaging in. For example, if the company has a program to recycle used products, that program is an example of Product Stewardship.

Comparison of company to its competitors: This page presents an argument as to whether the target company is a leader in sustainable practices, or whether they are a laggard.

Team bio page: Names of all team members with a picture and a short bio.

Project source page: All web sites, articles, or resources used must be listed on this page in MLA format. 